\title{
A Planning Proposal for Building Institutional Capacity of Community Development Centers from a Social Work Perspective
}

\author{
Siham Ali Ahmed Al Qabandi ${ }^{1}$ \\ ${ }^{1}$ College of Social Sciences, Department of Sociology and Social Work, Kuwait University, Kuwait \\ Correspondence: Siham Ali Ahmed Al Qabandi. E-mail: morganiteinstitute@yahoo.com
}

Received: May 30, 2019

Accepted: June 21, 2019 Online Published: November 19, 2019

doi:10.5539/ass.v15n12p73

URL: https://doi.org/10.5539/ass.v15n12p73

\begin{abstract}
The present study aimed at identifying the reality of the institutional capacities available to the community development centers from a social work perspective: organizational capacities, human capacities, planning capabilities, funding capacities and information capabilities in light of their objectives, knowledge of the difficulties that limit the institutional capacities of the community development centers.

The results of the study showed that the reality of the institutional capacities available to the development centers came with a medium degree on the macro scale, and institutional capacity came in descending order. The study showed a number of difficulties and developed a planning proposal to build and support the institutional capacities of the community development centers in Kuwait.
\end{abstract}

Keywords: capacity building, Community Development Centers in Kuwait, social planning

\section{Introduction}

The issue of building the capacities of institutions working in the social field is problematic in terms of its ability to carry out development and construction tasks, especially with regard to the nature of its composition, the skills, expertise and human capacities necessary to achieve these tasks, its awareness of the needs of its local communities (ALSCO, 2000, p. 7).

Institutional capacity building is the process of developing and strengthening the skills, capacities, processes and resources that organizations and communities need to survive in a rapidly changing world. In this context, community development centers are an essential tool of the Ministry of Social Affairs and Labor represented in the social development sector. These centers have been used to achieve its objectives to promote community development and improve the institutional work in serving the targeted segments in order to raise the citizen's status and improve its economic and social conditions. The total social assistance provided by the Ministry of Affairs in Kuwait to eligible categories during the last five years reached (119) million Kuwaiti dinar to (260) million dinar annually, at a monthly rate in 2016: support between (559) dinars to more than (800) dinars per month per person. That was in order to provide the best care methods for the development of their abilities and social and psychological rehabilitation (Ministry of Social Affairs and Labor Annual Report, 2015).

The Community Development Centers seek to focus on some of the issues and ethical phenomenon that has a general impact and to start from it to achieve practical results on the ground. They also aim at benefiting from distinguished competencies and attracting interested volunteers who wish to participate in the fields of work and activities. The development of joint projects of the family have the integration of the leaders and members of the centers and representatives of the bodies active in the issues of the family and put them in the seminars in preparation for the launch and promotion of development interaction with the concerns of the Kuwaiti family. The treatment of the balanced developments that emerged from contemporary life and is one of the negative phenomena, and attention to children's issues by adopting initiatives elevate care and embracing it, and to promote a culture of virtue and social purity between the Kuwaiti family members in the community.

\subsection{Problem of the Study}

Civil society organizations and their services are considered as a very important pillar for the protection and construction of societies and work to evaluate them and protect them from any deviations, as weak capacity may represent the most difficult bottlenecks that impede the efforts of developing countries to achieve rapid socially oriented development, it strives to raise the standard of living of citizens and establish social justice values. 
Therefore, there should be increased interest from the State of Kuwait in the process of capacity-building, as this process plays a key role in driving economic and social development. There have been numerous national strategies, plans and programs aimed at achieving economic and social development in the community, both at the national and local levels. However, it focused primarily on human resources development (training dimension), omitting the strengthening of community organizations and reforming their institutional structures and legal frameworks (human organizational dimension). Capacity-building should be based on the integration of a set of reform strategies that support the efficient, effective and positive functioning of all actors of society, including government, the private, this supports the idea of social justice in society, which is consistent with the concept of community governance. Therefore, the Kuwaiti government has not succeeded through long decades of economic reform attempts to achieve the desired development, where, during those past decades, it has not adopted a clear and comprehensive strategic approach to building community capacities that takes into account its different dimensions, it can be relied upon as a mechanism for strategic intervention, supportive of social justice and community governance, to achieve inclusive and sustainable community development. Hence, the problem lies in the absence of a clear and realistic integrated strategy to build community capacity in Kuwait.

\subsection{Questions of Study}

This study tries to answer the following questions:

1: What are the available institutional capacities of the community development centers in Kuwait?

2: What are the difficulties that limit the institutional capacities (Administrative, organizational, planning, human, human, finance, informatics) in community service centers?

3: What is the proposed planning scenario to support and build institutional capacity in community service centers from the perspective of social planning in social work?

\subsection{Study Objectives}

The present study aimed at describing the status of the institutional capacities of the community development service centers: organizational capacity, human capacity, planning capacity, funding capacity and information capacity in light of their objectives

\subsection{Determinants of the Study}

- The study was limited to community service centers in Kuwait.

-The study was applied on a target sample of the employees of the community development centers, social workers, psychologists and trainers, permanent social workers, and direct contact in providing services to the beneficiaries in the community service centers in Kuwait during the period from the beginning of October until the end of December 2017.

-The results of this study are limited to the study community and similar communities.

\subsection{Study Concepts}

\subsubsection{Institutional Capacity Building}

As mentioned by Brown. L., and Macintyre (2000) capacity building is to improve the institutional ability to achieve goals. The ultimate goal of capacity-building is to provide an institution capable of performing its functions efficiently and effectively through a set of interactive and interrelated processes through which individuals, organizations and communities are assisted in order to develop performance. it is also the ability to adapt to changes in the surrounding environment.

Therefore, the researcher considers that the concept of institutional capacity building for community service centers can be defined as a series of interrelated and overlapping stages and procedures that lead to achieving specific objectives. This process involves a range of activities, such as training, technical support, planning, financing, communication, Human resources development and others.

\subsubsection{Community Development Centers}

The Community Development Center (CDC) is defined as an essential tool of community development management that is used to achieve its developmental goals that enable citizens to achieve improvement in their quality of life. Therefore, it has become of great importance as it affects the human needs as well as the distribution of services. Through a distinguished cadre of social workers and an integrated team; the center is established to provide tangible and mental services and assistance. 


\subsection{The Theoretical Guidelines for the Study}

- Capacity Building Approach:

- The institutional capacity building entries are classified into three entries: (NGO Services Center, 2004, pp. 5-6; Deborah, 2001, p. 230).

1- Entrance to capacity building from the outside to the inside. The institutional capacity building and technical specialist from outside the organization identifies the ideal image that the organization should have, and then together with the staff of the organization, the specialist conducts an assessment to identify the strengths and weaknesses of the organization. The outcome of the evaluation process begins with planning to address deficiencies, ultimately aiming to achieve the best image of the organization.

\section{2- The entrance of capacity building from the inside out.}

Here the external specialist begins working with the institution by asking a set of questions about the organization's mission, goals, activities and performance. He also examines the written records and shareholders' documents and concludes with a session to express opinions and comments. He compares different views, then analyzes differences, identifies issues and plans change.

This approach assumes that the organization is able to identify its needs and problems and it is able to solve them in line with its mission and objectives. It uses the "confrontation" method. The technical support specialist faces the problems and weaknesses of the organization and gives it the opportunity to find suitable solutions, especially if part of the problem is the same institution. This method aims to highlight the difference between the optimal situation that "the current situation" should be the relationship between the technical support specialist of the institution must be managed with caution and care based on trust and constructive confrontation.

\section{3- Integrated Capacity Building Approach}

It depends on the mixture between the two previous entries and is applied as follows:

The institutional capacity-building specialist provides technical support from outside the institution as well as the institutional evaluation manager of the institution, assesses the capabilities of the institution and is applied collectively. Therefore, it plans to address the weaknesses identified through the institutional assessment tool. Despite the many standards, the diversity of their areas, and the wide range of change, each institution can identify areas and activities for which it is a priority.

This approach is based on "participation", which aims to involve the organization in the assessment and planning process to build its capacity. This direct approach depends on the specific nature of each institution and its basic needs. a plan is developed specifically to build the capacity of each institution to ensure that it meets its own needs and requirements.

\section{Previous Studies}

The researcher reviewed many studies in the field and the following are some of these studies:

Costantini et al. (2015) conducted a study entitled "Analytical Survey of Civil Society Organizations in Palestine". This study aimed to enhance the participation of civil society in public affairs and in the preparation, implementation and monitoring of development strategies, through cooperation with the European Union, to achieve the objective of the study, the researchers used the descriptive analytical and content analysis approaches, the study tools were numerous and the researchers used questionnaire, interview, and focus groups, the study population reached (2793) organizations in the West Bank and Gaza Strip, the study concluded a set of results:

- Identify key civil society organizations and key structures in Palestinian civil society; and identify key constraints and capacity-building needs.

- Identify key policy areas in which CSOs can successfully participate, taking into account their current capacities and political context, and the current situation of the civil society sector.

- Develop a practical strategy to enhance the participation of civil society in policy dialogue and governance.

The study recommended several recommendations including:

- Support the establishment and strengthening of monitoring mechanisms with regard to the use of funds to implement activities and services provided to the community.

- Support the development of funding plans for activities other than service delivery and relief, and funding plans targeting different categories of organizations

Pfister (2014) conducted a study entitled "A Systematic Framework for Measuring Sustainability in Civil Society 
Organizations Engaging in Development" An Integrated Approach to CSOs working in Support of Development for Planning, Evaluation, Increasing Project Impact and Sustainability of the Organization", the study aims to develop a framework for special measurement for civil society organizations working in the field of development and relief to manage the sustainability process by measuring the successes provided by these organizations in the areas of: Credibility, continuity, resilience to constraints, reliability, stability, resistance, and effectiveness of the Organization's resources in all services provided.

The researcher used the questionnaire tool, which was distributed to several international organizations working in the field of development and relief in several countries and were as follows: (31) in Germany, (45) in Switzerland, (57) in Britain, (52) organization in the United States of America, the number of questionnaires distributed was (185) questionnaires, and the most important results of the study were the following:

That all organizations use different methodologies to measure sustainability and evaluate their work, these methodologies depend on the size of the institution, the scope of its work, its available resources, the administrative nature of the institution, and the extent of the management culture and orientation, therefore, a unified framework for these organizations had to be developed; leads the organization to work; works to increase the impact of projects and services provided better.

The most important recommendations of the study were the need to ascertain the capacity of the methodology developed in different countries, and the need to disseminate and develop the methodology to suit different sectors to improve the quality of work in non-profit organizations.

Wadongo (2014) conducted a study entitled "Performance Management and Evaluation in Non-profit Organizations: an Embedded Mixed Methods Approach". The study aimed to identify the development and validation of a model that examines the impact of management practices on the performance and effectiveness of the institution in non-profit organizations in Kenya, the researcher used different methods for the study, where he collected and analyzed data using both quantitative and descriptive methods, through questionnaires, where (1000) questionnaires were distributed, and conducting interviews and focus groups for 13 non-profit organizations operating in Kenya. The results of the study included:

- Non-profit organizations in Kenya have many different characteristics that complicate institutional building, which affect managerial performance.

- Management performance relates to variables such as performance planning, performance objectives, information collection methods, rewards, performance of the project implementation system, and the strength and consistency of the organizational structure.

The study made several recommendations, the most important of which are:

That modern technology programs have to be used to analyze data and get results, the researcher recommends that a study be conducted to identify new indicators to measure institutional performance and evaluate the effectiveness of work in the institution to be compatible with all sectors in different countries.

Julian (2013) conducted a study entitled "Relationship between Strategic Planning and Organization's Performance in Non-governmental Organizations (NGOs): a case of Action aid 'Kenya. The study aimed to learn how strategic planning can be used to improve the performance of approved programs in relief work in Kenya; it is a case study of NGOs in Kenya.

The researcher used the descriptive analytical method in his study, and conducted a case study on (5) partner institutions in relief work, he collected information in a number of ways through interactive interviews with (12) senior and executive departments, in addition to access to a large amount of files and documents of the targeted organizations and analysis, and the most important results of the study:

There is a positive and statistically significant relationship between the planning process and the improvement of institutional work performance in non-profit organizations working in the field of relief work in Kenya, and target organizations have a high performance in the work; this is due to the use of different planning tools at all stages of work and the use of different strategic planning systems to improve performance.

The study recommended that evaluations be undertaken of projects implemented in the nature of administrative, institutional and other performance and measure the results and impact of the services provided; to develop more robust strategic plans with a strong vision and mission.

Al-Ziyadi (2011) conducted a study entitled "Organizational development requirements and strategies in light of the challenges of the business environment". The study aimed to identify the requirements of organizational development in light of the challenges facing the environment, through the analysis of organizational 
development theories contained in the administrative literature related to the responsibility of managing the project of change and organizational development and stages and strategies, the research reached several results, the most important of which are:

Organizations adopt a proactive approach to change and development that allows them to chart the future direction, and choose the appropriate strategic mode in the light of internal and external environmental variables, it also allows it to develop and maintain its relationship with the environment in which it operates by defining the goals and objectives of the various processes and activities it conducts.

The researcher recommended achieving some kind of harmonization between the activities of the organizations and the various changes that occur in their economic and social environment, a strategy that takes into account available capacities and challenges, and prioritize a development strategy commensurate with the needs, characteristics and preparations of individuals within the organization.

\section{Methodology of Study}

The present study used a descriptive analytical approach and depended on social survey as a comprehensive inventory on the team workers and the social workers in the development centers.

\subsection{Population of the Study}

The society of the study is composed of (321) (social workers, psychologists, administrators and employees working in whole or in part in the community development centers), distributed in (19) centers (Ministry of Social Affairs and Labor Kuwait, 2017).

\subsection{The Study Sample}

A sample of the study population was selected from the full-time study community in the community development centers. The study sample was (293) which is almost $91 \%$ of the study population.

Table 1. Properties of sample study

\begin{tabular}{|c|c|c|}
\hline Gender & $\mathrm{N}$ & $\%$ \\
\hline Male & 76 & $25.60 \%$ \\
\hline Female & 217 & $74.06 \%$ \\
\hline \multicolumn{3}{|l|}{ Age } \\
\hline $20-25$ & 27 & $9.22 \%$ \\
\hline $26-35$ & 158 & $53.92 \%$ \\
\hline $36-45$ & 95 & $32.42 \%$ \\
\hline $46+$ & 13 & $4.44 \%$ \\
\hline Average age & 34 & \\
\hline \multicolumn{3}{|l|}{ Marital status } \\
\hline Unmarried & 53 & $18.09 \%$ \\
\hline Married & 212 & $72.35 \%$ \\
\hline Divorced & 21 & $7.17 \%$ \\
\hline Widowed & 7 & $2.39 \%$ \\
\hline \multicolumn{3}{|l|}{ Qualification } \\
\hline Diploma - Secondary school & 181 & $61.77 \%$ \\
\hline Bachelor of Social services & 64 & $21.84 \%$ \\
\hline Bachelor of commerce & 30 & $10.24 \%$ \\
\hline Different specialties in Science & 18 & $6.14 \%$ \\
\hline Total & 293 & $100 \%$ \\
\hline \multicolumn{3}{|l|}{ Job } \\
\hline Accountant & 30 & $10.24 \%$ \\
\hline Social specialist & 55 & $18.77 \%$ \\
\hline Secretary - Administration & 130 & $44.37 \%$ \\
\hline Training coordinator & 47 & $16.04 \%$ \\
\hline Psychological specialist & 12 & $4.10 \%$ \\
\hline Center manager & 21 & $7.17 \%$ \\
\hline
\end{tabular}




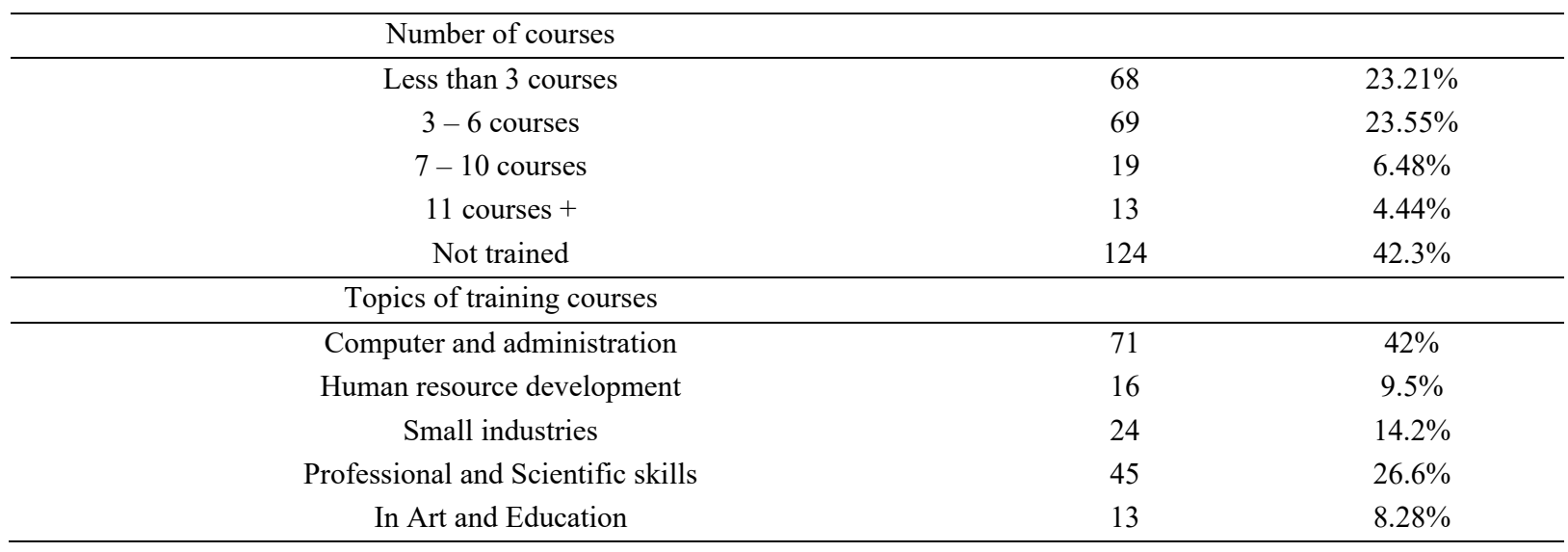

\subsection{Study Tools}

3.3.1 Questionnaire I related to institutional capacities available in community development centers). This tool was developed using the theoretical literature contained in the study. The tool consisted of (66) items, divided into five subjects.

\subsubsection{Validity of the Tool}

In order to verify the veracity of the study, it was presented to (10) specialized and experienced jury members. The validity of the content was verified by presenting the study tool to a group of experienced and competent jury members. The researcher adopted the items approved by $(80 \%)$ and more of the jury members. based on the observations of the arbitrators, $f(5)$ items were worded and deletion of (6) items applied. The questionnaire was finalized and it consisted of (60) items. Every items was given graded scale according to three-scale measurement as following: (3) for strong degree, (3) for medium degree, and (1) for weak degree.

\subsubsection{Reliability of the Tool}

The questionnaire was calculated by re-testing the test-re-test and then the test was conducted on a sample of the team members and the social workers at the center from outside the sample of the study (10) vocabulary. The questionnaire was applied and re-applied at a time interval (15) days. Reliability coefficient using the Spearman correlation coefficient before and after application $=(0.91)$ which means the strength of the validity of the questionnaire and its validity for application. Statistical analysis of data and information was carried out using the statistical program SPSS A + version 20.

3.3.2 Questionnaire II: related to difficulties that limit institutional capacity .It included five specific questions directed at the sample members to reveal the difficulties they faced.

3- Suggestions: related to the proposals of the sample members to support and build capacities available in community service centers.

\section{Governance Standard:}

- The researcher followed the code of ethics of the NASW.

In order to facilitate the passing of judgments on the degree, the reality of the institutional capacity of the community development centers in Kuwait, the three-dimensional cells were determined in this study. The range $(2=1-3)$ was calculated and then divided by the number of cells to obtain cell length, $0.66=322$ This value was then added to the lowest value in the scale $(0.67)+1=1.67$ and so the length of cells became as follows:

- If the probable average of sample responses is (1.67) or less, the reality of the institutional capacities of the community development centers in Kuwait is weak.

- If the probable average of sample responses ranged from (1.68 to 2.34) to the responses of the sample members, the reality of the institutional capacities of the community development centers in Kuwait is at medium degree.

- If the arithmetic average of the sample responses varies between (3.00-2.35), the reality of the institutional capacities of the community development centers in Kuwait is significantly strong.

\section{Study Results}

1: What is the reality of the institutional capacities available to the community development centers in Kuwait? 
Table 2. Ranking the available institutional capacities of the centers (descending order) according to the responses of the sample members

\begin{tabular}{cccccc}
\hline $\mathbf{N}$ & Domains & Total weights & Probable ratio & Probable average & Ranking \\
\hline $\mathbf{1}$ & Administrative and organizational capacities & 7999 & 0.76 & 2.28 & 1 \\
$\mathbf{2}$ & Human capacity & 7537 & 0.71 & 2.14 & 2 \\
$\mathbf{3}$ & Information and technological capabilities & 7418 & 0.70 & 2.11 & 3 \\
$\mathbf{4}$ & Planning and Development Capabilities & 7336 & 0.69 & 2.06 & 4 \\
$\mathbf{5}$ & Funding Capacities & 6831 & 0.65 & 1.94 & 5 \\
\hline & Total & 37121 & 0.70 & 2.11 & \\
\hline
\end{tabular}

Table 2 shows that the overall probable mean of the study areas reached (2.11). This means that the respondents believe that the reality of the institutional capacities of the community development centers in Kuwait is medium (according to the criterion of the judgment adopted in the study). The sample responses to the study areas ranged between (1.94-2.28), which means that their responses were medium in each field of study. The area of administrative and organizational capacity came first with total probable weights (7999) which constitutes probable ration of $(76 \%)$ and probable average of (2.28), that is, administrative and managerial capacity available were medium which is due to the feeling of the respondents that some centers do not fully comply with the objective criteria in evaluating the work performance and achievement of the goals. They also feel that the centers do not adhere effectively to form specialized committees to monitor the quality of services provided. That also relates to the absence of the involvement of staff in participation in decision-making, and the absence of some centers of the existence of a system of reward and punishment for employees. That required the administrative leaders in the centers to make more effort to avoid some shortcomings in the administrative aspects in their positions. The results of the present study are consistent with the results of the study of Naji (2006) and the study of Abdel Moneim (2007).

In the second rank is the domain of human capacities with total probable weight of (7537), which is a probable raio of $(71 \%)$ and a probable average of (2.14), meaning that the human capacities available in the centers came to a medium degree. Although the centers pay close attention to their human power, there are some shortcomings in terms of training on what is new. The training courses should include new and innovative ways of working in line with the requirements of their work at the center.

This was confirmed by the study of Barakat and Sha'aban (2002) on the need to train employees in institutions to increase their ability to deal with different challenges. This is in line with Frederic and William's 1993 study, which emphasized the importance of institutional capacity-building by building the capacity of training personnel to design, implement and follow up on their programs and projects.

In the third place was the domain of information and technological capabilities, with probable weights of (7418), which is a probable ratio of (70.\%) and a probable average of (2.11). that means that information and technological capabilities available in the centers are medium in the viewpoint of the sample. In other words, these results should lead the decision makers in the community service centers to make efforts in the field of networking between their database and the information centers at the level of the bodies operating in the same field. There should be a periodic survey through emailing for the opinions of customers in the level of services provided. And As Rashwan (2010) noted, the success of the capacity-building process within any organization requires the establishment of an information base characterized by realism and continuous renewal of information and data.

In the fourth place was the domain of the planning and development capacity with total probable weights of (7336) probable percentage of $(0.69 \%)$ and probable average of $(2.06)$, which means the planning and development capacities available in the centers were medium. The Center provides programs and projects using the latest Technology. Field research is carried out periodically to know the needs of the beneficiaries of the Center. The Center constantly evaluates its programs and projects to avoid weaknesses in performance. The Center uses experts and specialists for the quality of services and projects.

The results of the studies and theoretical research show that the results of the table are consistent with the results of the study of Hijazi (2006) Amri (2004), and Mustafa (2007).

Finally, the domain of the financing capacity with total probable weights (6831), probable percentage of $(0.65 \%)$, 
and a probable average of (1.94). In other words, the funding capacity available in the centers is medium. accordingly, the issue of financial resources and financing capacity building is vital in any institution since funding is the lifeblood of the institution. Building capabilities of institution depends on self-funding by Investing and developing institution resources to ensure sustainability in the community and contribute to the institution's other institutional capacity-building activities. This is done through careful and transparent planning by the administration which provides the center with data on financial systems for project financing, the exchange of methods of the budget within the center, and the center cover programs and project financing, and the cost of producing a budget.

Table 3. Sample responses to the reality of available managerial and organizational capacities

\begin{tabular}{|c|c|c|c|c|c|}
\hline $\mathrm{N}$ & Item & $\begin{array}{c}\text { Total } \\
\text { weights }\end{array}$ & $\begin{array}{l}\text { Probable } \\
\text { ratio }\end{array}$ & $\begin{array}{l}\text { Probable } \\
\text { average }\end{array}$ & Order \\
\hline 5 & There is a continuous monitoring and evaluation of the Center's work & 711 & 0.81 & 2.43 & 1 \\
\hline 2 & $\begin{array}{l}\text { The rules and regulations governing the work achieve internal control } \\
\text { of the Center's employees. }\end{array}$ & 701 & 0.80 & 2.39 & 2 \\
\hline 4 & $\begin{array}{l}\text { The Center follows a time plan for programs and activities on specific } \\
\text { dates }\end{array}$ & 700 & 0.80 & 2.39 & 2 \\
\hline 1 & $\begin{array}{l}\text { There is a common policy for the center work specified in accordance } \\
\text { with the regulation. }\end{array}$ & 691 & 0.79 & 2.36 & 4 \\
\hline 12 & $\begin{array}{l}\text { The regulation allows flexibility and ease in implementing plans and } \\
\text { programs at the center. }\end{array}$ & 679 & 0.77 & 2.32 & 5 \\
\hline 8 & $\begin{array}{l}\text { Decisions are made based on sufficient information and data at the } \\
\text { Center. }\end{array}$ & 678 & 0.77 & 2.31 & 6 \\
\hline 9 & $\begin{array}{l}\text { Objective criteria are put in place to evaluate the work performance } \\
\text { and achieve the objectives of the Center }\end{array}$ & 662 & 0.75 & 2.26 & 7 \\
\hline 11 & $\begin{array}{l}\text { The Center sets up flexible rules to provide timely and appropriate } \\
\text { service. }\end{array}$ & 660 & 0.75 & 2.25 & 8 \\
\hline 3 & $\begin{array}{l}\text { The staff of the center participates in the development of plans and } \\
\text { programs. }\end{array}$ & 639 & 0.73 & 2.18 & 9 \\
\hline 7 & $\begin{array}{l}\text { The center's service delivery procedures are adjusted to customer } \\
\text { requests }\end{array}$ & 637 & 0.72 & 2.17 & 10 \\
\hline 10 & $\begin{array}{l}\text { The Center set up specialized committees to monitor the quality of the } \\
\text { services provided. }\end{array}$ & 623 & 0.71 & 2.13 & 11 \\
\hline 6 & $\begin{array}{l}\text { There is a specific system of reward and punishment for employees } \\
\text { within the center. }\end{array}$ & 618 & 0.70 & 2.11 & 12 \\
\hline & Relative strength of dimension & \multicolumn{3}{|c|}{ The probable average of dimension } & 2.28 \\
\hline
\end{tabular}

Table 3 shows that the probable weights of the sample of the study in relation to the organizational management capacity reached (7999), which is a probable ratio of (76\%) and a probable average of (2.28). Those weights came in the first rank in the community development centers, indicating that there is a level of administrative and organizational capacity at an average level

Table 4. Sample responses to the reality of available human capacities

\begin{tabular}{|c|c|c|c|c|c|}
\hline No & Items & $\begin{array}{c}\text { Total } \\
\text { weights }\end{array}$ & $\begin{array}{l}\text { Probable } \\
\text { ratio }\end{array}$ & $\begin{array}{l}\text { Probable } \\
\text { average }\end{array}$ & Order \\
\hline 29 & $\begin{array}{l}\text { The Working Group recognizes the operational policies and work } \\
\text { programs }\end{array}$ & 690 & 0.78 & 2.35 & 1 \\
\hline 25 & $\begin{array}{l}\text { There is a willingness and acceptance of the nature of work at the } \\
\text { center }\end{array}$ & 680 & 0.77 & 2.32 & 2 \\
\hline 30 & $\begin{array}{l}\text { Employees are aware of their roles and functions in providing the } \\
\text { service. }\end{array}$ & 671 & 0.76 & 2.29 & 3 \\
\hline 31 & $\begin{array}{l}\text { The Center's management encourages good social relations between } \\
\text { employees. }\end{array}$ & 666 & 0.76 & 2.27 & 4 \\
\hline
\end{tabular}




\begin{tabular}{|c|c|c|c|c|c|}
\hline 28 & $\begin{array}{l}\text { The Center holds training courses to improve the performance of } \\
\text { employees. }\end{array}$ & 653 & 0.74 & 2.23 & 5 \\
\hline 27 & The staff have expertise to help them improve their performance. & 625 & 0.71 & 2.13 & 6 \\
\hline 26 & $\begin{array}{l}\text { Employees recognize the mechanisms of teamwork in providing } \\
\text { service to beneficiaries. }\end{array}$ & 606 & 0.69 & 2.07 & 7 \\
\hline 35 & Training courses include new and innovative methods of work & 599 & 0.68 & 2.04 & 8 \\
\hline 34 & $\begin{array}{l}\text { Employees are trained in the new application of working methods in } \\
\text { community development }\end{array}$ & 596 & 0.68 & 2.03 & 9 \\
\hline 32 & $\begin{array}{l}\text { Monitored appropriate resources and capabilities to train staff } \\
\text { according to their specialties are set }\end{array}$ & 592 & 0.67 & 2.02 & 10 \\
\hline 33 & $\begin{array}{l}\text { The training courses take into account the individual differences and } \\
\text { the different experiences of the employees. }\end{array}$ & 585 & 0.67 & 2 & 11 \\
\hline 36 & $\begin{array}{l}\text { Training courses for employees meet with the requirements of their } \\
\text { work at the Center }\end{array}$ & 574 & 0.65 & 1.96 & 12 \\
\hline & Relative strength of dimension & 0.71 & \multicolumn{2}{|c|}{$\begin{array}{l}\text { The probable average of } \\
\text { dimension }\end{array}$} & 2.14 \\
\hline
\end{tabular}

Table 4 shows that the probable weights of the responses of the sample of the study in relation to human capacities reached (7537), which is a probable ratio of (71\%) and probable average of (2.14). And ranked second in the capacity available at community development centers, indicating that there is a "medium level" human capacity availability.

Table 5. Responses of respondents to the reality of the available information and technological capabilities

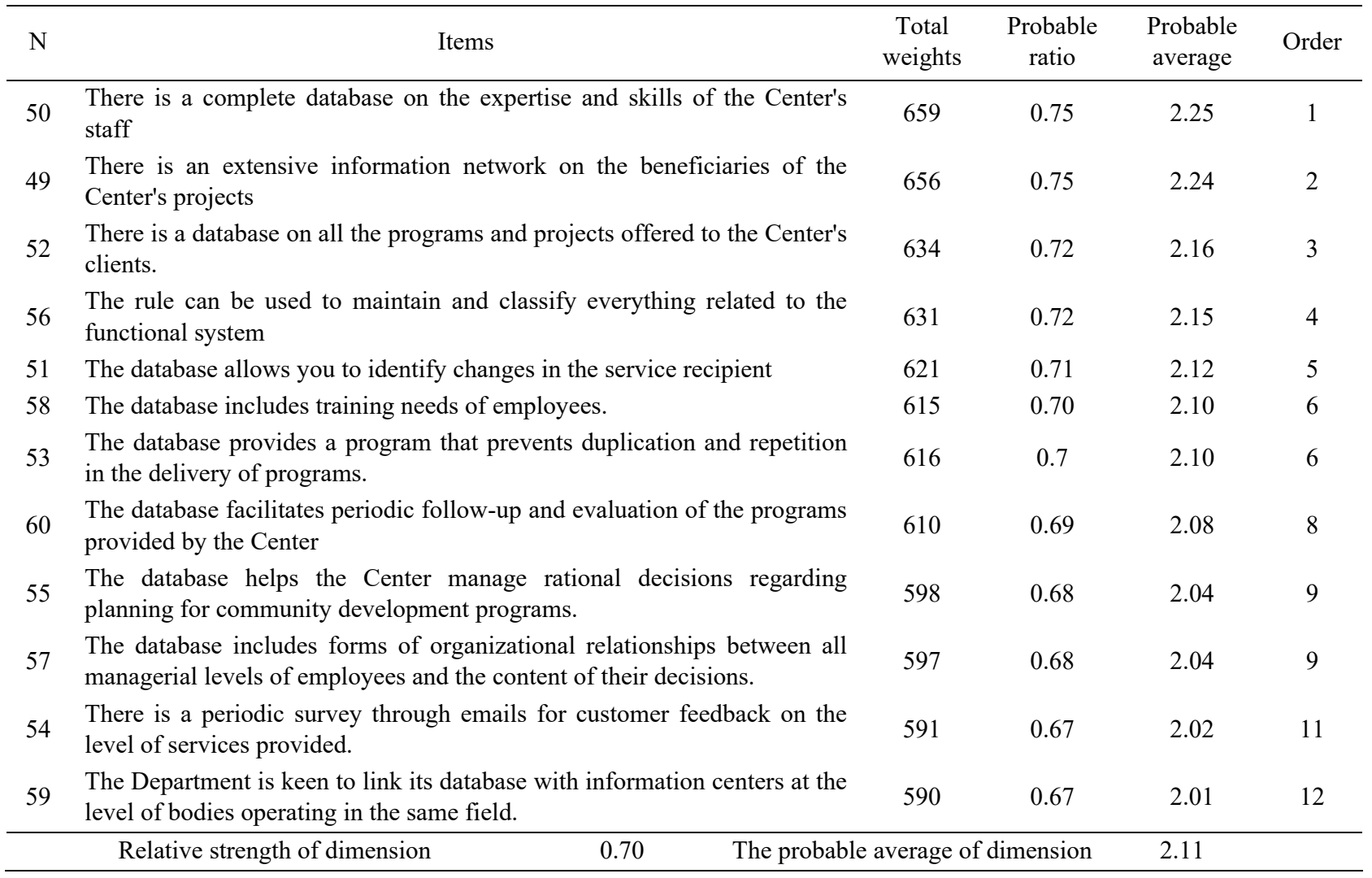

Table 5 shows that the probable weights of the responses of the study sample in terms of information capacity reached (7418), which is a probable ratio of $(70 \%)$ and a probable average of $(2.11)$, ranked third in the capacities available in the community development centers which indicates that there is a "medium level" of information capacity. 
Table 6. Sample responses to the reality of available planning and development capacities

\begin{tabular}{|c|c|c|c|c|c|}
\hline $\mathrm{N}$ & Items & $\begin{array}{c}\text { Total } \\
\text { weights }\end{array}$ & $\begin{array}{l}\text { Probable } \\
\text { ratio }\end{array}$ & $\begin{array}{c}\text { Probable } \\
\text { average }\end{array}$ & Order \\
\hline 23 & Direct beneficiaries to prioritize their program and project needs. & 624 & 0.71 & 2.13 & 1 \\
\hline 16 & $\begin{array}{l}\text { The Center's plan includes priorities and alternatives for the provision of } \\
\text { diversified services to beneficiaries. }\end{array}$ & 626 & 0.71 & 2.13 & 1 \\
\hline 17 & $\begin{array}{l}\text { Organizes seminars and meetings to explain how to benefit from the } \\
\text { programs and projects of the Center. }\end{array}$ & 625 & 0.71 & 2.13 & 1 \\
\hline 24 & $\begin{array}{l}\text { The Center's management ensures coordination between programs and } \\
\text { projects. }\end{array}$ & 617 & 0.70 & 2.11 & 4 \\
\hline 19 & $\begin{array}{l}\text { There is a plan to follow up on the utilization of projects provided in the } \\
\text { development of society. }\end{array}$ & 609 & 0.69 & 2.08 & 5 \\
\hline 20 & Employ the resources available to maximize beneficiaries' benefits. & 610 & 0.69 & 2.08 & 5 \\
\hline 18 & $\begin{array}{l}\text { The administration is concerned with the opinions of beneficiaries } \\
\text { regarding the quality of the services they receive }\end{array}$ & 600 & 0.68 & 2.05 & 7 \\
\hline 22 & $\begin{array}{l}\text { Discuss beneficiaries' views on improving the level of services at the } \\
\text { center. }\end{array}$ & 595 & 0.68 & 2.03 & 8 \\
\hline 15 & $\begin{array}{l}\text { The Center continuously evaluates its programs and projects to avoid } \\
\text { weaknesses in performance }\end{array}$ & 594 & 0.68 & 2.03 & 9 \\
\hline 13 & $\begin{array}{l}\text { Field research is conducted periodically to identify the needs of the } \\
\text { beneficiaries of the center. }\end{array}$ & 588 & 0.67 & 2.01 & 10 \\
\hline 21 & $\begin{array}{l}\text { The Center uses experts and specialists in the quality of services and } \\
\text { projects }\end{array}$ & 582 & 0.66 & 1.99 & 11 \\
\hline \multirow[t]{2}{*}{14} & The Center offers programs and projects using technological innovations & 565 & 0.64 & 1.93 & 12 \\
\hline & Relative strength of dimension & of dimens & & 2.06 & \\
\hline
\end{tabular}

Table 6 shows that the probable weights of the sample responses of the study sample in terms of planning and development capacities reached (7336), which is a probable rate of $69 \%$ and a probable average of (2.06), ranked fourth in the Community development centers. That indicates there is an average level of planning and development capacity.

Table 7. Sample responses to the reality of available financial financing capacities

\begin{tabular}{|c|c|c|c|c|c|}
\hline $\mathrm{N}$ & Items & $\begin{array}{c}\text { Total } \\
\text { weights }\end{array}$ & $\begin{array}{l}\text { Probable } \\
\text { ratio }\end{array}$ & $\begin{array}{l}\text { Probable } \\
\text { average }\end{array}$ & Order \\
\hline 41 & The Center always needs to obtain funds from various quarters. & 602 & 0.68 & 2.05 & 1 \\
\hline 46 & $\begin{array}{l}\text { The Center encourages donations to finance some productive } \\
\text { projects. }\end{array}$ & 594 & 0.68 & 2.03 & 2 \\
\hline 45 & The annual budget plan barely covers expenses for the center. & 590 & 0.67 & 2.01 & 3 \\
\hline 48 & The Department works to increase sources of funding by all means. & 585 & 0.67 & 2 & 4 \\
\hline 38 & $\begin{array}{l}\text { There are multiple ways to obtain financing from multiple } \\
\text { governmental and non-governmental entities }\end{array}$ & 585 & 0.67 & 2 & 4 \\
\hline 42 & $\begin{array}{l}\text { The Center organizes annual campaigns to mobilize donations and } \\
\text { donations. }\end{array}$ & 562 & 0.64 & 1.92 & 6 \\
\hline 43 & $\begin{array}{l}\text { The Center provides data on financial systems to follow up on } \\
\text { project finance }\end{array}$ & 563 & 0.64 & 1.92 & 6 \\
\hline 44 & The Center studies and manages funding problems. & 553 & 0.63 & 1.89 & 8 \\
\hline 39 & $\begin{array}{l}\text { There is a systematic system for reviewing disbursement methods } \\
\text { from the budget within the Center. }\end{array}$ & 554 & 0.63 & 1.89 & 8 \\
\hline 40 & The Center's annual budget plan is flexible and transparent. & 551 & 0.63 & 1.88 & 10 \\
\hline 47 & $\begin{array}{l}\text { The Center's management explains to beneficiaries the sources of } \\
\text { funding for their projects }\end{array}$ & 551 & 0.63 & 1.88 & 10 \\
\hline 37 & $\begin{array}{l}\text { The Center's budget covers the cost of programs and financing of } \\
\text { productive projects. }\end{array}$ & 541 & 0.62 & 1.85 & 12 \\
\hline & Relative strength of dimension & \multicolumn{3}{|c|}{ The probable average of dimension } & 1.94 \\
\hline
\end{tabular}


Table 7 shows that the probable weights of the responses of the study sample in relation to financial and financial capacity reached (6831), which is a probable ratio of $(65 \%)$ and a probable average of (1.94).

Question 2: What are the difficulties that limit the institutional capacities in community development centers?

Table 8 . The difficulties faced by workers

\begin{tabular}{|c|c|c|c|}
\hline Difficulties & & $\%$ & order \\
\hline \multicolumn{4}{|l|}{ Organizational and administrative difficulties } \\
\hline lack of a specific policy that regulates the Center's programs throughout the year & 95 & 41 & 1 \\
\hline weak organizational structure resulting in overlapping roles and specialties among employees & 60 & 26 & 2 \\
\hline shortage in technical and administrative competencies in the center & 53 & 22 & 3 \\
\hline Routine procedures such as: Documentary and central course of work & 48 & 19 & 4 \\
\hline slow implementation of ministerial and administrative decisions & 37 & 16 & 5 \\
\hline \multicolumn{4}{|l|}{ Planning difficulties } \\
\hline The rigidity of the plan and its lack of resilience to accommodate all societal variables & 86 & 37 & 1 \\
\hline Centralization of the plans makes them disproportionate to the diversity of citizens' needs & 72 & 31 & 2 \\
\hline There is no prior planning of programs in light of the actual needs of citizens & 53 & 23 & 3 \\
\hline The plans are short-term and vary according to personal preferences and are not adhered to & 46 & 20 & 4 \\
\hline Poor participation of planners makes them inadequate and ineffective & 19 & 8 & 5 \\
\hline \multicolumn{4}{|l|}{ human difficulties } \\
\hline Random recruitment and the presence of large numbers of workers without the need for them & 198 & 85 & 1 \\
\hline Lack of specialized human cadres qualified to work centers & 75 & 32 & 2 \\
\hline Lack of training programs related to human development and development & 62 & 27 & 3 \\
\hline $\begin{array}{l}\text { The job description is not complied with in accordance with the qualification when distributing the } \\
\text { employees of the center }\end{array}$ & 57 & 24 & 4 \\
\hline \multicolumn{4}{|l|}{ Financing difficulties } \\
\hline Lack of regular funding for the programs provided and their dependence on donations and grants & 233 & 100 & 1 \\
\hline Weak incentives and rewards for the Center's employees & 166 & 71 & 2 \\
\hline The budget is general and there is no special funding for development projects & 78 & 33 & 3 \\
\hline Lack of access to available funding for program implementation & 27 & 16 & 4 \\
\hline \multicolumn{4}{|l|}{ Information difficulties } \\
\hline Lack of computers and networks in the centers & 185 & 79 & 1 \\
\hline Lack of database and information for programs at the level of all centers & 177 & 76 & 2 \\
\hline Difficulty in obtaining information about clients of the Center & $70^{1}$ & 73 & 3 \\
\hline The scarcity of qualified persons in dealing with the computer and codifying the information & 98 & 42 & 4 \\
\hline There is no link between centers for information exchange and customer service & 32 & 14 & 5 \\
\hline No difficulties were mentioned & 60 & & \\
\hline
\end{tabular}

Question 3: What is the proposed planning scenario to support and build institutional capacity in community centers from the perspective of social planning in social work?

Table 9. The proposals of the employees of the community service centers

\begin{tabular}{|c|c|c|c|}
\hline Suggestions & & $\%$ & order \\
\hline \multicolumn{4}{|l|}{ Organizational and administrative suggestions. } \\
\hline Organizing the administrative relationship between the leaders and all the employees of the center & 55 & 19 & 5 \\
\hline $\begin{array}{l}\text { Periodic and continuous evaluation of the achievements of the Center to identify the strengths and } \\
\text { weaknesses }\end{array}$ & 92 & 31 & 1 \\
\hline Make an organizational plan according to the circumstances and needs of each center & 75 & 26 & 3 \\
\hline Simplifying procedures for obtaining service and facilitating the customers of the center & 67 & 23 & 4 \\
\hline Make a job description for all employees explaining all disciplines to prevent interference & 77 & 26 & 2 \\
\hline \multicolumn{4}{|l|}{ Planning suggestions } \\
\hline Availability of sufficient flexibility in the annual plans received from the Ministry & 48 & 16 & 2 \\
\hline
\end{tabular}




\begin{tabular}{|c|c|c|c|}
\hline Defining the items of the plan according to each department of the Center, with its financial allocations & 88 & 30 & 1 \\
\hline $\begin{array}{l}\text { Participation of employees in the development and implementation of the action plan within a } \\
\text { community framework }\end{array}$ & 62 & 21 & 2 \\
\hline Establish a clear policy for the center defined by long-term plans for programs & 49 & 17 & 3 \\
\hline \multicolumn{4}{|l|}{ Human suggestions } \\
\hline Provide leaders, administrators and technicians with experience & 125 & 43 & 3 \\
\hline To reduce the density of unqualified workers in the center & 137 & 47 & 2 \\
\hline Intensifying the training courses in the center to support all employees in all specialties & 146 & 50 & 1 \\
\hline \multicolumn{4}{|l|}{ Funding suggestions } \\
\hline Develop funding plans for the programs annually according to the needs of each center & 176 & 60 & 1 \\
\hline Increase incentives and rewards for the Center's employees & 148 & 71 & 3 \\
\hline $\begin{array}{l}\text { Search for sources of funding and volunteering to support community development programs and } \\
\text { projects }\end{array}$ & 27 & 16 & 4 \\
\hline \multicolumn{4}{|l|}{ Information suggestions: } \\
\hline Design a database and integrated information at the level of all centers & 157 & 54 & 2 \\
\hline Provide centers with equipment and specialists in information networks and databases & 98 & 33 & 4 \\
\hline $\begin{array}{l}\text { Increasing the networking between the centers for the exchange of information and services for the } \\
\text { benefit of customers }\end{array}$ & 47 & 16 & 5 \\
\hline $\begin{array}{l}\text { Linking the Center's information network with all departments of the Ministry of Social Affairs and } \\
\text { other centers to increase the exchange of information and services }\end{array}$ & 72 & 24 & 3 \\
\hline Supporting the role of the media in spreading the center's services and its role in the community & 29 & 10 & 5 \\
\hline
\end{tabular}

These suggestions helped to develop a schematic proposal for building the institutional capacities of the community development centers from the perspective of the social planning method in social work. This schematic proposal goes as following:

Objective of the schematic proposal:

- Building the institutional capacity of community development centers as a local institution to achieve their objectives and use these capacities to support the dynamics of development after the provision of resources and capabilities. Capacity building becomes a strategy for achieving sustainable development in society.

Mechanisms of the planning proposal in building the institutional capacities of the from the perspective of the social planning method in social work.

Organizational and administrative capacity building including:

-Periodic and continuous evaluation of the Center's achievements to identify strengths and weaknesses

-Organization: the administrative relationship between the leaders and social workers and all the staff

-Organizational planning: An organizational chart is drawn up according to the conditions and needs of each center. It specifies the administrative structure and job descriptions of all the staff of the center, explaining all disciplines to prevent overlap and duplication of work and helps in reaching rational decisions related to the planning of the programs implemented by the center.

-Simplification and facilitation: on the clients of the Center in the procedures for obtaining the service.

-Reward and punishment: the establishment of a specific system agreed to reward the committed and punish the neglected and contrary to his duties.

Mechanisms for building human and human capacities for workers including:

-Education: Provide the social worker with a set of theoretical knowledge, linked to modern trends in planning, management and knowledge of methods of classification and classification of data and information and methods of advanced statistical analysis. How to make and make a rational decision

-Training: Intensifying the training courses to support all staff in all disciplines and monitoring the appropriate financial and financial resources for training and that the training programs include ways to cope with deficiencies during work.

-Appointment: in accordance with the need to effectively reduce the intensity of non-qualified workers in the center and to choose the human element appropriate to the nature of the work entrusted to him. 
-The use of experts: provide leaders, administrators and technicians with experience in the nature of work in the centers to create a second row and help them to improve their performance in the future.

-Encouragement: To promote cooperative relations between the social workers and employees and to create a social atmosphere based on the friendliness and understanding between the center's management and employees.

- Mechanisms for building planning capacity, including:

-Development of plans: to build a clear policy and a detailed study of the terms of the plan and according to the needs of each section of the Center and specific financial allocations for him and the methods of expenses and the timeline for implementation.

-Participation and dialogue: with the staff in the development of the executive plan to work within the community and commitment to it

-Innovation: in the development programs and projects provided by the Center to its clients.

-Setting priorities: directing clients to prioritize and replace their needs to ensure satisfaction and to achieve better quality of services provided.

Mechanisms for building financing capacities, including:

-Financial planning: the development of policies and the drawing of plans and the design of programs and activities according to the financial and physical needs of each center, provision of financial allocations that help to complete the work

-Motivation: Increase incentives and rewards for the center's employees and create an encouraging atmosphere to work

- Research: sources of funding and donors. And volunteers to support the programs of community development and projects as well as study the difficulties and funding of funding.

Mechanisms for building information capacities, including:

-Design and construction: for a database and integrated information at the level of all centers, including: data relating to information about the Center's customers and the level of services provided by the Center and the needs of customers accurately and programs that benefited customers to prevent recurrence.

-Providing centers with equipment and specialists in information networks and databases

-Networking: Increasing operations between the centers for the exchange of information and services for the benefit of customers, as well as linking the information network of the Center with all departments of the Ministry of Social Affairs and other centers to increase exchange .

\section{References}

Abdel-Halim, R. (2004). NGO Board Views on the Possibility of Implementing the Networking Approach. Research published at the 17th Scientific Conference of Social Work, Cairo, Faculty of Social Work, Helwan University.

Abu- Almaaty, M. (2011). Recent Trends in Social Work Areas. Nour El Eman Printing.

Al Emary, M. (2004). The Relationship between Networking and Capacity Building of NGOS. Research published in the Journal of Studies in Social Work and Humanities, No. 17, Part II, October Annual Report of the Ministry of Social Affairs and Labor (2015).

Al-Ziyadi, D. (2011). The role of NGOs in achieving human development in Egypt (Unpublished doctoral thesis). Faculty of Commerce, Ain Shams University, Cairo, Egypt.

Brown, L., Fond, A., \& Macintyre, K. (2000). Measuring Capacity Building. New Orleans, Measure Evaluation Tulane University.

Caroline, S. (1995). Strength Leaning the Capacity of Ngo: Cases of Smell Enter Pries Development a Genies in Africa Oxford interlace.

Costantini, G. et al. (2015). Analytical Survey of Civil Society Organizations in Palestine. Introduction to the European Union, Palestine.

Eade, D. (2001). Capacity Building an Approach to people centered Development. London: Oxfam.

Economic and Social Commission for Western Asia. (2002, September 7). NGO Capacity Building Issues, Recommendations and Follow-up to World Conferences, Cairo. 
Farah, S. (2008). Role of networks in institutional capacity-building for NGOs working in the field of environment and sustainable development: A study applied to member organizations of the Arab Network for Environment and Sustainable Development. Journal of Studies in Social Work and Human Sciences, 24(2), 689-835. Cairo, Helwan University.

Frederic, J., \& William, A. (1993). From peas To Capitalists. Community Development Journal, 28(2). https://doi.org/10.1093/cdj/28.2.129

Hegazy, S. (2006). The Relationship between Organizational Capacity Building Requirements and Achieving the Quality of NGO Projects. Research published at the 19th Conference, Faculty of Social Work, Helwan University.

Julian, O. (2013). Relationship between strategic planning and organization's performance in non-governmental organizations (NGOS): A case of action aid Kenya. The degree of master of business administration school of business runiversity of Nairobi.

Khater, A. (2007). Social Work Historical View. Alexandria, Modern University Office.

Mark, S. (2000). Capacity Building, A New Way of Doing Business for Development Assistance Organizations. Canada, Institute on Governmence, Policy Brief No. 6 January,

NGO Services Center. (2004). NGO Capacity Building - in a series of guides issued by the NGO Services Center, Cairo (pp. 5-6).

Ouda, A. (2010). The requirements of building the institutional capacities of NGOs to face the flood disaster in Aswan: A study applied to community development societies in the villages of Abu Rish. Journal of Studies in Social Work and Humanities, 28(6).

Pfister, S. (2014). Sustainability Measurement Framework for Development Aid NGOs - An integrated Approach for Development Aid NGOs to plan evaluate and increase the Impact of Projects and the Sustainability of the Organization of the University of St. Gallen School of Management Economics Law Social Sciences and International Affairs to obtain the title of Doctor of Philosophy in Management.

Rashwan, A. (2004). The relationship between the organizational determinants of the NGOs as members of the network of environmental protection and the achievement of the network for its objectives. Research published in the 17th Scientific Conference of Social Service, Faculty of Social Work, Helwan Unibversity.

Rich, J. (1998). Demystifying Development Practical Capacity Building Experiences of African NGOS (p. 28). UK: intra c publication.

Wadongo, B. (2014). Performance management and evaluation in non-profit organizations: An embedded mixed methods approach. Submitted to the University of Bedfordshire.

Wagdy, B., \& Yusry, Sh. (2002). Towards a Proposed Program for Organizing the Community to Help Community Development Societies in Facing the Challenges of Globalization, A Study on Community Development in Southern Cairo. Research published in Social Studies, Humanities, Vol. 1, Faculty of Social Work, Helwan University.

\section{Copyrights}

Copyright for this article is retained by the author(s), with first publication rights granted to the journal.

This is an open-access article distributed under the terms and conditions of the Creative Commons Attribution license (http://creativecommons.org/licenses/by/4.0/). 